Fall 10-5-2018

\title{
The English Voyage of Pietrobono Burzelli
}

Evan A. MacCarthy

West Virginia University, evan.maccarthy@mail.wvu.edu

Follow this and additional works at: https://researchrepository.wvu.edu/faculty_publications

Part of the Diplomatic History Commons, European History Commons, Musicology Commons, and the Music Performance Commons

\section{Digital Commons Citation}

MacCarthy, Evan A., "The English Voyage of Pietrobono Burzelli" (2018). Faculty Scholarship. 870.

https://researchrepository.wvu.edu/faculty_publications/870

This Article is brought to you for free and open access by The Research Repository @ WVU. It has been accepted for inclusion in Faculty Scholarship by an authorized administrator of The Research Repository@ WVU. For more information, please contact ian.harmon@mail.wvu.edu. 


\title{
The English Voyage of Pietrobono Burzelli
}

\author{
EVAN A. MACGARTHY
}

May princes desire you, kings and dukes praise you, and may anyone in the whole world who sees you marvel.

-Aurelio Brandolini, De laudibus musicae et Petriboni libellus, lines 191-92 ${ }^{1}$

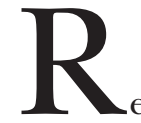

eading the many verses composed in honor of the preeminent musician Pietrobono (ca. 1417-97), we encounter valuable reports of his reputation as one of the finest instrumentalists of his day, his performance style, and the repertory he played and sang. ${ }^{2}$ Unusually for the period, there is ample documentary evidence that already by the 1450 s Pietrobono had become a celebrated and sought-

Research for this article was supported by fellowships and grants from Villa I Tatti (the Harvard University Center for Italian Renaissance Studies), College of the Holy Cross, and West Virginia University. Earlier versions of this material were presented at the Medieval and Renaissance Music Conference, Certaldo, Italy, 2013; the New England Chapter of the American Musicological Society, Amherst, MA, 2013; and at the 63rd Annual Meeting of Renaissance Society of America, Chicago, 2017. I am especially grateful to Bonnie Blackburn and Lewis Lockwood, whose ideas, questions, and shared documents concerning Pietrobono and other instrumentalists at Ferrara have significantly improved this essay. I have also benefited from the comments of Margaret Bent, Andrea Canova, Camilla Cavicchi, Leofranc Holford-Strevens, and the anonymous readers for this journal.

1 Kathryn Krug, trans., in F. Alberto Gallo, Music in the Castle: Troubadours, Books, and Orators in Italian Courts of the Thirteenth, Fourteenth, and Fifteenth Centuries, trans. Anna Herklotz (Chicago: University of Chicago Press, 1995), 128-29.

2 Ibid., 69-135; Tim Shephard, Echoing Helicon: Music, Art and Identity in the Este Studioli, 1440-1530 (New York: Oxford University Press, 2014), 58-62; and Bonnie J. Blackburn, "The Foremost Lutenist in the World': Pietrobono dal Chitarino and his Repertory," Journal of the Lute Society of America, forthcoming.

The Journal of Musicology, Vol. 35, Issue 4, pp. 431-459, ISSN 0277-9269, electronic ISSN 1533-8347. (C) 2018 by The Regents of the University of California. All rights reserved. Please direct all requests for permission to photocopy or reproduce article content through the University of California Press's Reprints and Permissions web page, www.ucpress.edu/journals.php?p=reprints. DOI: https://doi.org/10.1525/JM.2018.35.4.431 
after musician. ${ }^{3}$ Duke Francesco Sforza (1401-66) corresponded with him several times between 1455 and 1461. Musicians were sent from the Sforza court in Milan to study with him in Ferrara. ${ }^{4}$ The dancing master and Sforza court poet Antonio Cornazano (ca. 1430-84) wrote several verses praising him and his performing. ${ }^{5}$ In 1457 a medal was cast in his honor by the Venetian artist Giovanni Boldù $\left(f l\right.$. 1454-75) ${ }^{6}$ Borso d'Este presented him with many lavish gifts on top of his salary as court musician. Private students sought him out for instruction, as demonstrated by a 1465 teaching contract, in which Pietrobono agrees to teach his student each day in the student's home "the art of music on the cithara as well as how to play seven songs well and worthily," all in exchange for six yards of black cloth and a gold ducat-but only if the student succeeds in learning the seven songs. ${ }^{7}$

The "art of music" championed by Pietrobono connected him not only to the oral and unwritten traditions of courtly improvisers and street singers performing across the Italian peninsula, but also to repertories

${ }^{3}$ Recent accounts of Pietrobono's life include Lewis Lockwood, "Pietrobono and the Instrumental Tradition at Ferrara in the Fifteenth Century," Rivista italiana di musicologia 10 (1975): 115-33; idem, Music in Renaissance Ferrara, 1400-1505: The Creation of a Musical Center in the Fifteenth Century (Oxford and New York: Oxford University Press, 2009), 103-18; Evan A. MacCarthy, "What's in a Name? The Origins of Pietrobono Burzelli," Tijdschrift van de Koninklijke voor Nederlandse Musiekgeschiedenis 65 (2015): 5-11; Camilla Cavicchi, "Pietrobono Burzelli, detto dal Chitarino," in Dizionario biografico degli Italiani 83 (2015), http:/ /www.treccani.it/enciclopedia/pietrobono-burzelli-detto-dal-chitarino_(DizionarioBiografico)/ (accessed 19 May 2018); and Blackburn, "'The Foremost Lutenist.'”

4 Guglielmo Barblan, "Vita musicale alla corte sforzesca," in Storia di Milano 8 (Milan: Fondazione Treccani degli Alfieri per la storia di Milano, 1956), 787-852, at 803; Lockwood, "Pietrobono and the Instrumental Tradition," 124-26; idem, Music in Renaissance Ferrara, 109-10; Alessandra Bollini, "L'attività liutistica a Milano dal 1450 al 1550: nuovi documenti," Rivista italiana di musicologia 21 (1986): 31-60, at 37-39.

5 Nino Pirrotta, "Music and Cultural Tendencies in 15th-Century Italy," Journal of the American Musicological Society 19 (1966): 127-61, at 139-41, 144-46; Shephard, Echoing Helicon, 60; and Blackburn, "'The Foremost Lutenist.'”

${ }^{6}$ Lore Börner, Die italienischen Medaillen der Renaissance und des Barock (1450-1750) (Berlin: Mann, 1997), 53n154, pl. 35; Nicoletta Guidobaldi, "Le mythe du 'nouvel Orphée' dans deux portraits musicaux de Giovanni Boldù," in "La musique, de tous les passetemps le plus beau..." ": Hommage à Jean-Michel Vaccaro, ed. François Lesure and Henri Vanhulst (Paris: Klincksieck, 1998), 195-206; Wolf-Dietrich Löhr, "Höfische Stimmung: Künstlerkonkurrenz und Fürstenrepräsentation auf einer Medaillenserie Giovanni Boldùs von 1457," in Die Renaissance-Medaille in Italien und Deutschland, ed. Georg Satzinger (Münster: Rhema, 2004), 9-54, at 12-21; Shephard, Echoing Helicon, 61-62; and MacCarthy, "What's in a Name?," 5-8.

7 Ferrara, Archivio di Stato, Archivio Notarile Antico di Ferrara, Notaio Mengo dall'Armi, matr. 113, pacco 1, prot. 1465, fol. 30 (4 May 1465); transcribed in Adriano Franceschini, Artisti a Ferrara in etá umanistica e rinascimentale: testimonianze archivistiche 1, Dal 1341 al 1471 (Ferrara: Gabriele Corbo, 1993), 1:648-49 (\#1044). A 1494 letter from a Don Acteon in Mantua offers titles of works taught by Pietrobono (Mantua, Archivio di Stato, Archivio Gonzaga, B. 1233). On these documents see Lockwood, Music in Renaissance Ferrara, 116-18; and William F. Prizer, "The Frottola and the Unwritten Tradition," Studi musicali 15 (1986): 3-38, at 23-27. 
circulating in written versions. ${ }^{8}$ From the adoring lines composed by the humanist scholar Aurelio Brandolini (ca. 1454-97), also a musician known for extemporizing, we learn about the repertory Pietrobono performed: "whatever songs Britain sings, beloved of the Muses, and France, no less favored by the Muses, the beseeching laments of Spain in her wide lands, and the songs of serious Italy." Elsewhere, Brandolini remarks that Pietrobono played "French songs and British, Spanish laments and Italian melodies." 10

Since Pietrobono's cosmopolitan performing career brought him to nearly every important court in Italy in the second half of the fifteenth century, it is no surprise that he had access to such a varied collection of songs. Still, one is left wondering how and where he learned these repertories, such as the English songs referenced by Brandolini. Might it have been through contact with English musicians working in Ferrara, where Pietrobono lived, where he had connections, such as the composer and music teacher Robertus de Anglia ( $f$. 1454-74), the English singer Anna, the English harpist John, or the singer and priest from London also named John? ${ }^{11}$ Alternatively, could Pietrobono have come to know the English polyphonic song repertory through circumstances similar to those that caused these works to be copied into mid-fifteenth-century continental manuscripts? ${ }^{12}$

${ }^{8}$ Recent scholarship on street performers and oral poetry includes Camilla Cavicchi, "Musici, cantori e 'cantimbanchi' a corte al tempo dell'Orlando Furioso," in L'uno e l'altro Ariosto in corte e nelle delizie, ed. Gianni Venturi (Florence: L. S. Olschki, 2011): 263-89; Massimo Rospocher and Rosa Salzberg, "Street Singers in Italian Renaissance Urban Culture and Communication," Journal of the Social History Society 9 (2012): 9-26; Blake Wilson, "Canterino and Improvvisatore: Oral Poetry and Performance," in The Cambridge History of Fifteenth-Century Music, ed. Anna Maria Busse Berger and Jesse Rodin (Cambridge and New York: Cambridge University Press, 2015), 292-310; Luca Degl'Innocenti and Massimo Rospocher, "Street Singers: An Interdisciplinary Perspective," Italian Studies 71 (2016): 149-53; and Blake Wilson, "The Cantastorie/Canterino/Cantimbanco as Musician," Italian Studies 71 (2016): 154-70.

9 Brandolini, De laudibus musicae et Petriboni libellus, trans. Krug in Gallo, Music in the Castle, 124-25 (lines 103-6).

${ }^{10}$ Brandolini, Eiusdem de laudibus Petriboni, lines 13-14; trans. Krug in ibid., 130-31 (lines 13-14).

${ }_{11}$ Discussions of these musicians appear in Ann Besser Scott, "English Music in Modena, Biblioteca Estense, $\alpha$. X. 1,11 and Other Italian Manuscripts," Musica Disciplina 26 (1972): 145-60; David Fallows, "Robertus de Anglia and the Oporto Song Collection," in Source Materials and the Interpretation of Music: A Memorial Volume to Thurston Dart, ed. Ian D. Bent (London: Stainer \& Bell, 1981), 99-128; Lockwood, Music in Renaissance Ferrara, 55-62, 120-26; and Bonnie J. Blackburn, "Anna Inglese and Other Women Singers in the Fifteenth Century: Gleanings from the Sforza Archives," in Sleuthing the Muse: Essays in Honor of William F. Prizer, ed. Kristine Forney and Jeremy L. Smith (Hillsdale, NY: Pendragon Press, 2012), 237-52.

12 Examples might include the two-voice English songs in the manuscript Porto, Biblioteca Pública Municipal, Ms 714, the songs by English composers in the Mellon Chansonnier (New Haven, Yale University, Beinecke Library, Ms 91), or even the songs sent on behalf of John Tiptoft to Giovanni de' Medici in 1460. The most recent discussion 
In addition to these probable points of contact with English music and musicians, a long-overlooked notarial document in the Archivio di Stato in Ferrara offers compelling evidence that Pietrobono, together with his tenorista Francesco Malacise, made a trip to England on behalf of the Ferrarese court. In what follows I introduce this document, consider what new light it sheds on Pietrobono's biography, explore the purpose of and Pietrobono's role in the diplomatic mission, and propose possible repertories he encountered or exchanged while traveling. These findings demonstrate the important function of musicians in diplomatic relations. They also underscore the ongoing value of archival research in studies of fifteenth-century music.

\section{Pietrobono's Will and Testament}

On 12 August 1466, thirty-one years before his death, Pietrobono had a testament drawn up by the notary Mengo dall'Armi, whom Pietrobono regularly employed in the 1450 s and 1460 s for contracts, sales, and property deals in Ferrara. ${ }^{13}$ The testament specifically states that the next day Pietrobono was planning to set off "ad partes Anglie." Fearing calamities that might befall him on this journey, Pietrobono had put his property in order and arranged for a notary to prepare a will. This document, until now unknown to music historians, is the first substantial evidence of any journey by Pietrobono north of the Alps, aside from a trip to the court at Buda in the late 1480s (fig. 1 and appendix).

of the English repertory in Porto 714 and the Mellon Chansonnier appears in David Fallows, ed., Secular Polyphony, 1380-1480, Musica Britannica, 97 (London: Stainer and Bell, 2014). A letter written by Ambrogio di Taverni in Venice to Giovanni de' Medici indicates that John Tiptoft, Earl of Worcester, in gratitude for the hospitality shown to him in Florence, sent a sealed scroll containing songs set to music, along with wishes that he could have sent more songs and a promise to do so soon. The letter is in Florence, Archivio di Stato, Mediceo avanti il Principato, filza VI, doc. 529 (17 December 1460). See Frank A. D'Accone, "A Late 15th-Century Sienese Sacred Repertory: Ms K. I. 2. of the Biblioteca Comunale, Siena," Musica Disciplina 37 (1983): 127-70, at 149-50; David Fallows, "Polyphonic Song in the Florence of Lorenzo's Youth Ossia: The Provenance of the Manuscript Berlin 78.C.28: Naples or Florence?," in La musica a Firenze al tempo di Lorenzo il Magnifico: congresso internazionale di studi, Firenze 15-17 giugno 1992, ed. Piero Gargiulo (Florence: L.S. Olschki, 1993), 47-61, at 57; Curt S. Gutkind, Cosimo de' Medici: Pater Patriae, 1380-1464 (Oxford: Clarendon Press, 1938), 213; James Haar and John Nádas, "Antonio Squarcialupi: Man and Myth," Early Music History 25 (2006): 105-68, at 121n53. Some discussions of this letter have suggested that Tiptoft sent these songs in 1466; in fact the letter is clearly dated 17 December 1460, while he was still in Italy.

${ }^{13}$ Ferrara, Archivio di Stato, Archivio Notarile Antico di Ferrara, Notaio Mengo dall'Armi, matr. 113, pacco 1, prot. 1465, fol. 33 (12 August 1466); transcribed in Franceschini, Artisti a Ferrara, 1:677-78 (\#1087). On Mengo's later service as chancellor to Ercole d'Este until Mengo's death in 1477, see Ugo Caleffini, Croniche: 1471-1494, ed. Franco Cazzola (Ferrara: Deputazione provinciale ferrarese di storia patria, 2006), 23, 57, 72, 221. 
Figure 1. Testament of Pietrobono Burzelli, dal Chitarino. Ferrara, Archivio di Stato, Archivio Notarile Antico di Ferrara, Domenico dall'Armi, matr. 113, p. 1, prot. 1465, cc. 33v-34r (12 August 1466), detail

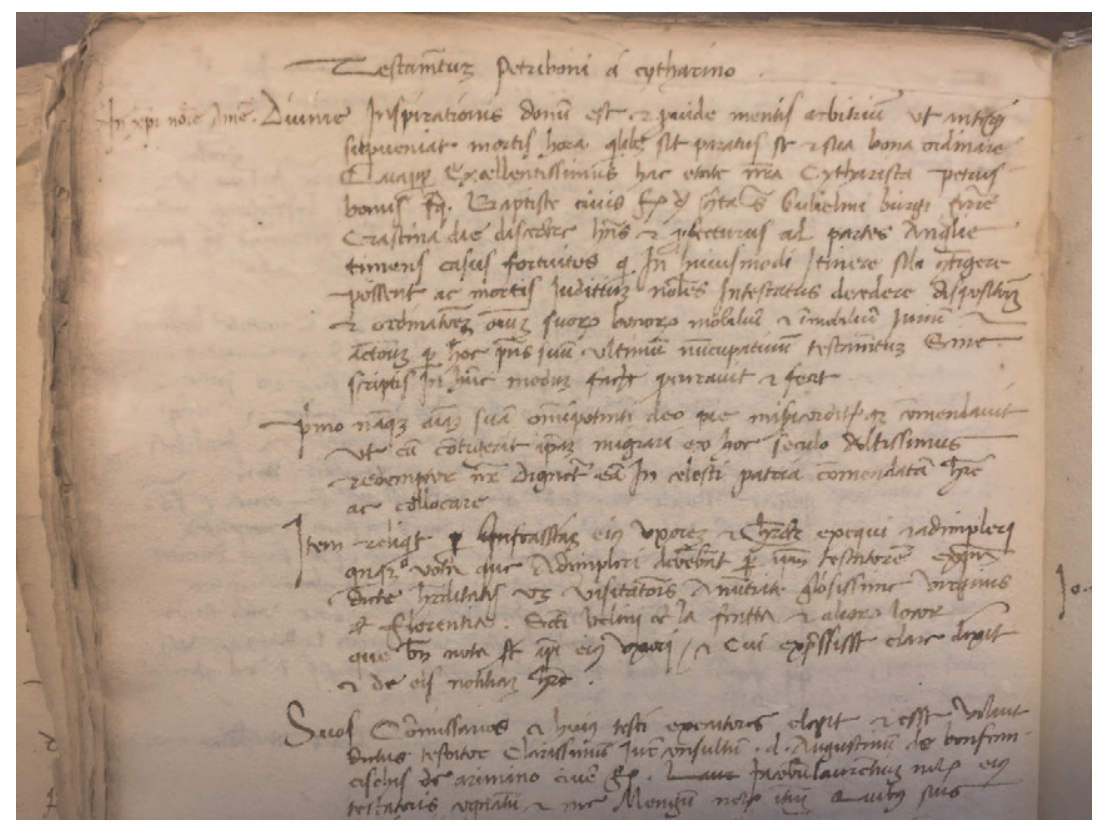

The 1466 testament amplifies our knowledge of Pietrobono's home life, presenting new and valuable details about his biography and family. His Venetian wife Antonia is cited as the sole heir to his property; there is no reference to children. Until now the only documentation for Pietrobono's wife and her Venetian roots was a description of her dowry. ${ }^{14}$

${ }^{14}$ Ferrara, Archivio di Stato, Archivio Notarile Antico di Ferrara, Notaio Mengo dall'Armi, matr. 113, pacco 1, prot. 1456 (15 July 1456); this is briefly discussed and partially transcribed in Enrico Peverada, "Vita quotidiana e cultura medievale nel Quattrocento," in Storia illustrata di Ferrara, ed. Francesca Bocchi (Milano: AIEP, 1987), 241-57, at 245. Antonia's dowry, managed by Pietrobono's mother Margherita, included "due letti forniti di guanciali, lenzuola e tenda da tenere al di sopra del letto. Altre due paia di lenzuola. Quattro mantelli. Otto tovaglie. Dieci tovaglioli. Tre cassoni. Un forziere. Quattro banchi. Una cassapanca. Tre tavoli. Tre sedie di legno di cui una ricoperta di pelle rossa. Otto sedie impagliate. Un cofano per la farina. Due paioli grandi stagnati. Due paia di molle da camino e una paletta. Due paia di alari. Due padelle. Due spiedi per le carni. Due gradelle. Una dozzina di scodelle di peltro e una dozzina di tazzine. Due bacili con due recipienti di bronzo. Ventriquattro mastelli di vino con fusti. Ventotto libre di filo. Quattro drappi. Sei camicie da donna. Un quadro e ancona con l'imagine della gloriosissima Vergine Maria."

The earliest known document for Pietrobono, dated 5 August 1441, refers to a gift to him of twenty gold ducats from Leonello d'Este, intended for clothing for his wife ("in 
Elsewhere we learn that Antonia's father (Messer Marco di Paulo) was a barber, the same occupation as Pietrobono's father (Messer Battista), and that her father's family hailed from the Giudecca in Venice. ${ }^{15}$ One of the witnesses to the will, Giovanni Tommaso da Reggio, lived in Pietrobono's house. He was later officially adopted by Pietrobono and his wife in 1471, perhaps as an apprentice; six years later he drowned in Cesena. ${ }^{16}$

If Pietrobono were to have died on his voyage to England, his wife would have been expected to fulfill his vows to visit shrines, including the church of the Santissima Annunziata in Florence, the basilica of San Bellino in Fratta Polesine (near Rovigo), and other places known well to her. In these instructions the reference to visiting Florence could indicate that Pietrobono had yet to see that city, at least not by summer 1466 and since making his vow. ${ }^{17}$ A decade later a letter from humanist Angelo Poliziano to Lorenzo de' Medici mentions Pietrobono as a model of excellent musicianship, suggesting their familiarity with his playing, or at least his reputation: "There is nothing new except that today Maestro Antonio degli organi [Squarcialupi] tried out the lute player of signor Ludovico [Sforza], who seems satisfactory enough to Maestro Antonio; I would compare him to David, not to say Pietrobono." ${ }^{18}$ The will also states that if

subsidium vestiendi uxorem suam"), thereby indicating that Pietrobono was probably married to someone else before his marriage to Antonia in 1456. Modena, Archivio di Stato, Camera Ducale Estense, Registri di Mandati, 1441-42, fol. 81r; cited in Lockwood, "Pietrobono and the Instrumental Tradition," 119; and Löhr, "Höfische Stimmung," 13. I would like to thank Bonnie Blackburn for drawing my attention to this clause in the document.

${ }^{15}$ Ferrara, Archivio di Stato, Archivio Notarile Antico di Ferrara, Notaio Antenore Balbi, matr. 243, pacco 1, prot. 1456 (25 May 1456), where Antonia is "filia M. Marci de Venetis barberii et uxor infrascriptis Petri Boni a chitarino." Documents produced by the same notary and by Mengo dall'Armi from later that summer provide additional details on Antonia's father.

16 On Giovanni Tommaso's adoption and subsequent death, see Luigi Napoleone Cittadella, Documenti ed illustrazioni risguardanti storia artistica ferrarese (Ferrara: Domenico Taddei, 1868), 294; and Ugo Orlandi, "Pietrobono dal Chitarrino: un musico virtuoso del Quattrocento," in Nell'età di Pandolfo Malatesta: Signore a Bergamo, Brescia e Fano agli inizi del Quattrocento, ed. Giorgio Chittolini, Elisabetta Conti, and Maria Nadia Covini (Brescia: Morcelliana, 2012), 211-20, at 14. The lawyer Giuliano Fantaguzzi's chronicle of Cesena records the tragic drowning in the river Savio in Cesena in 1477, but notarial acts from Ferrara in 1475 indicate an earlier death date. See Giuliano Fantaguzzi, Caos, ed. Michele Andrea Pistocchi (Rome: Istituto storico italiano per il Medio Evo, 2012), 2:32-33. On the Italian practice of adoptions as apprenticeship, see Philip Gavitt, Charity and Children in Renaissance Florence: The Ospedale degli Innocenti, 1410-1536 (Ann Arbor: University of Michigan Press, 1990), 189, 246-48.

17 Such a vow could of course have been professed toward a second visit to a shrine.

18 "Di nuovo non e altro per non che hoggi si pruova $\mathrm{M}^{\circ}$ Antonio degli organi col sonator di liuto del $\mathrm{s}^{\mathrm{r}}$ ludovico. Il quale pare satisfari assai a $\mathrm{m}^{\circ}$ antonio, e [ma?] propollo a davide e non che a pierbuono." Florence, Archivio di Stato, Mediceo avanti il Principato, filza 25, doc. 851 (17 October 1477); cited in Haar and Nádas, "Antonio Squarcialupi: Man and Myth," 117n38. For accounts of the devotional experiences of pilgrims visiting Santissima Annunziata in Florence, see Giovanni Zanovello, "In the Church and in the 
Pietrobono's wife Antonia were to die or remarry, control of his estate was to be assumed by the office of the "pauperes Christi" (or poveri di Cristo), a diocesan institution in Ferrara that oversaw the proper execution of testamentary bequests directed to pious or charitable works. ${ }^{19}$

The main executor of Pietrobono's estate was the highly regarded lawyer Agostino Bonfranceschi da Rimini (ca. 1437-79), who taught civil law at the Studio in Ferrara and later became one of Duke Ercole d'Este's closest advisers. ${ }^{20}$ Agostino was known to Pietrobono for at least a decade at this point, since Agostino had served as witness to many of the notarial acts concerning the 1456 marriage of Pietrobono and Antonia. Two other executors were the notary of this will, Mengo dall'Armi, and another notary named Jacopo Lorenzo de Vancio, referred to as a relative of Pietrobono; in fact, de Vancio was Pietrobono's brother-in-law. The house and garden in which this document was notarized and witnessed are located in the contrada of San Guglielmo, northeast of the Este castello and the cathedral, just beyond the medieval boundaries of the city. ${ }^{21}$ The remainder of the document is devoted to a sizable list of witnesses, individuals whose connections to Pietrobono and this act are also significant (table 1, fig. 2).

The witnesses were:

1. Biagio da Birago, a noble at the Este court and master of the stables, an important and well-paid post. ${ }^{22}$ Additional archival evidence indicates that Biagio also traveled to England with Pietrobono.

2. Leonello del Bruno, also an official at the Este court, who in the 1470s would oversee the collection of certain Ferrarese taxes. ${ }^{23}$

\footnotetext{
Chapel': Music and Devotional Spaces in the Florentine Church of Santissima Annunziata," Journal of the American Musicological Society 67 (2014): 379-428; and Philip Gavitt, "Corporate Beneficence and Historical Narratives of Communal Well-Being," in Renaissance Florence: A Social History, ed. Roger J. Crum and John T. Paoletti (Cambridge and New York: Cambridge University Press, 2006), 138-60, at 150-55. San Bellino was among the towns captured by the Venetians during the 1482-84 war.

19 On the history of this organization, see Antonio Samaritani, "Vescovo, Sindaco dei poveri di Cristo, Frati dei Penitenza a Ferrara nei secoli XIII-XV," Analecta TOR 14 (1980): 671-749.

20 Antonio L. Pini, "Bonfranceschi, Agostino," in Dizionario biografico degli Italiani 12 (1971), http://www.treccani.it/enciclopedia/agostino-bonfranceschi_(DizionarioBiografico) (accessed 19 May 2018).

${ }^{21}$ Other notarial records document several property transactions involving Pietrobono throughout the city during the 1450s and 1460s, as reported in Evan A. MacCarthy, "Pietrobono's Origins and His Companions," paper presented at the Annual Medieval and Renaissance Music Conference, Brussels, 2015.

22 Caleffini, Croniche: 1471-1494, 40, 152, 940. On 22 January 1476 Biagio was paid 30 marchesini by the Este court, while Pietrobono received 18 and the tenorista Francesco Malecise only 4.

${ }^{23}$ Ibid., 137. Leonello del Bruno was responsible for a court payment to Pietrobono on 9 April 1466. See Modena, Archivio di Stato, Camera Ducale Estense, Computisteria, Memoriale 18 "NN" (1466), 27 left.
} 
TABLE 1 .

Witnesses for 12 August 1466 testament of Pietrobono Burzelli

Nobilis vir Blasius de Birago de Mediolano aulicus et magister stabuli Illustrissimi domini nostri Ducis filius quondam ...

Leonellus de Bruno filius quondam Bartolomei de contrata Sancti Nicolai Superioris

Iacobus Laurentius de Vancis notarius filius Magistri Marci de contrata Bucecanalium

Hieronymus de Bonfrancischis de Arimino campsor filius quondam domini Ugulini de contrata Sancti Gregorii.

Franciscus filius quondam Blasii de Montepulzano civis Ferrarie de contrata Sancti Salvatoris eius Petriboni testatoris tenorista.

Michael Antonioli de Porto sartor habitator Ferrarie in contrata Sancti Salvatoris.

Iohannes Thomas dictus

Turchetus de Regio filius quondam Petri Pauli, habitator in domo dicti testatoris.

Mengus de Armis notarius
Nobleman Biagio da Birago of Milan, courtier and master of the stables of our Most Illustrious Lord Duke, son of the late ... Leonello Bruno, son of the late Bartolomeo, from the contrada of San Nicolò Superiore

Jacopo Lorenzo Vanci, notary, son of Messer Marco, from the contrada of Boccacanale

Girolamo Bonfranceschi da Rimini, banker, son of late Lord Ugolino, from the contrada of San Gregorio

Francesco, son of Biagio da Montepulciano, citizen of Ferrara, from the contrada of San Salvatore, the tenorista of the testifying Pietrobono

Michele Antoniolo of Porto, tailor, resident of Ferrara, from the contrada of San Salvatore

Giovanni Tommaso called Turchetto of Reggio, son of the late Pierpaolo, resident in the house of the said testator. Mengo dall'Armi, notary

3. Jacopo Lorenzo de Vancio, a notary in Ferrara and later at the Este court, the head of the court's property survey in 1469, and the brother-in-law of Pietrobono and one of the executors of his estate.

4. Girolamo Bonfranceschi, a banker and brother to Agostino, the main executor of Pietrobono's will; Girolamo agreed to a rental property deal with Pietrobono just a few months before the signing of this testament. ${ }^{24}$

5. "Francescus filius quondam Blasii de Montepulzano."

${ }^{24}$ Ferrara, Archivio di Stato, Archivio Notarile Antico di Ferrara, Notaio Mengo dall'Armi, matr. 113, pacco 1 (1466), fol. 10v. In October 1468 Pietrobono sold to Girolamo the property where the 1466 will had been notarized; see Cittadella, Documenti, 294. In 1473 Girolamo is listed as a treasurer for the Este court. See Caleffini, Croniche: 1471-1494, 30, 119. 
FIGURE 2. Witnesses for the testament of Pietrobono Burzelli, dal Chitarino. Ferrara, Archivio di Stato, Archivio Notarile Antico di Ferrara, Domenico dall'Armi, matr. 113, p. 1, prot. 1465, cc. 33v-34r (12 August 1466), detail

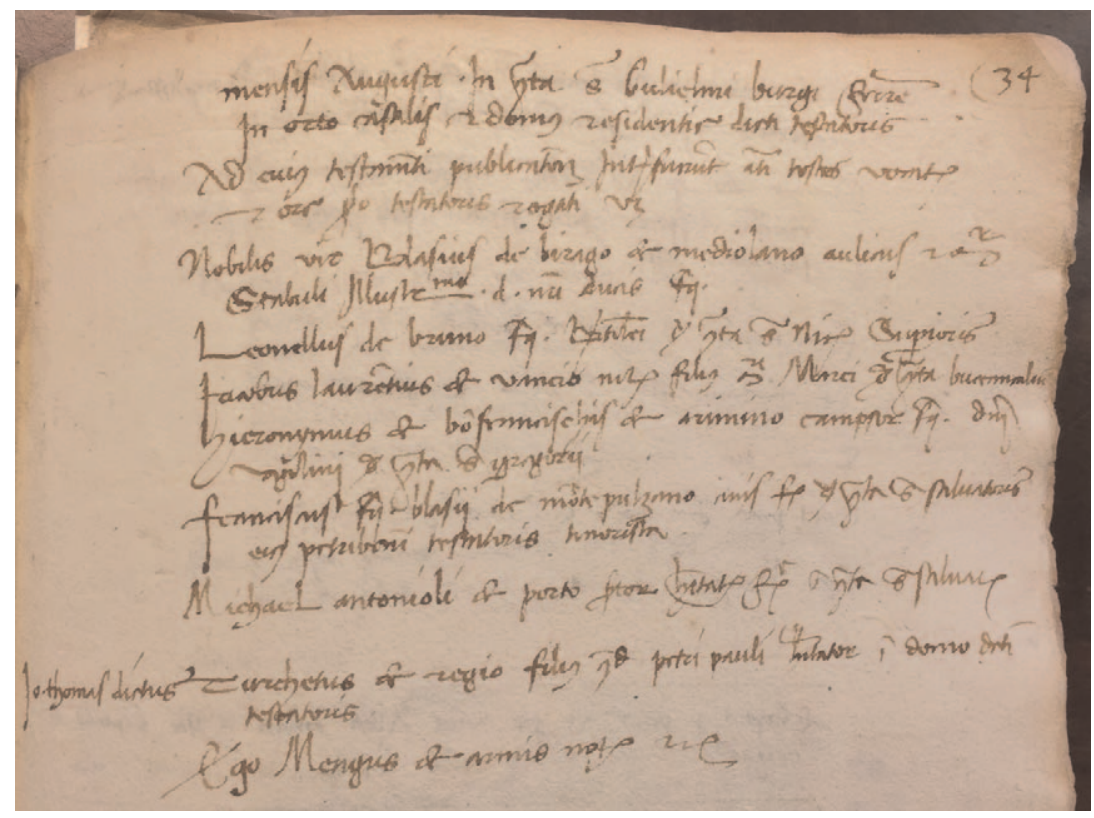

6. Michele Antonioli, a tailor from Porto residing in Ferrara.

7. Giovanni Tommaso da Reggio (called "il Turchetto"), who, as noted, was living in Pietrobono's house. Pietrobono adopted him five years later. ${ }^{25}$

8. Mengo dall'Armi, the notary for the testament.

The fifth witness is perhaps the most interesting. The will lists him as a citizen of Ferrara living in the contrada of San Salvatore and as Pietrobono's tenorista. ${ }^{26} \mathrm{He}$ is Francesco Malacise, who, as Lewis Lockwood and others have shown, appeared alongside Pietrobono in Estense court records from 1455 through at least $1476 .{ }^{27}$ Pietrobono's will offers new information that Francesco is from Montepulciano, which confirms, as

25 The name "Iohannes Thomas" was added in the margin. The notary had first listed him only as "Turchetus." He appears as a witness for another notarial act alongside Pietrobono in 1468, where he is again listed only as "Turchetto."

${ }^{26}$ Francesco lived in the same neighborhood as another witness, Michele Antonioli da Porto. While Francesco is listed as a "civis Ferrarie," Michele is a "habitator Ferrarie."

${ }^{27}$ Lockwood, "Pietrobono and the Instrumental Tradition," 123; idem, Music in Renaissance Ferrara, 105, 199-200; and Blackburn, "The Foremost Lutenist in the World.”" 
Keith Polk has proposed, that Pietrobono's long time tenorista was Italian. ${ }^{28}$ Francesco served as witness to other notarial acts concerning Pietrobono that date from more than ten years before this will. We also learn that Francesco had two brothers, Alessandro and Paulo Giovanni, and that their father was already present in Ferrara by $1430 .^{29}$

In the early 1470s, the humanist Aurelio Brandolini praised Francesco as a musician and as a companion of Pietrobono:

During all this his faithful companion holds firm and maintains the unmoving tenor, a faithful companion in art, even more faithful in love. He restrains the other's hands with measured steps, and forces them to go in fixed ways. If he did not do this, there would be no laws in song, and there would be no great music in the world. The one maintains the rhythms of the other; the latter is swayed by the former's reins; thus, the music of each aids the other. ${ }^{30}$

In addition to praising this musical duo, Brandolini composed another eight couplets (Ad Franciscum Petriboni comitem) that celebrate the strong bond of friendship between Pietrobono and Francesco:

Unice Pieridum clari conuictor alumni

Dulcis in arte comes, dux in amore potens,

Unde tibi tam leta dies, tam candida fulxit?

Quis deus in tantam duxit amicitiam?

Noui equidem; duxit tua mens, tua vivida virtus

Quique potest hostes iungere verus amor.

Nam per uirtutes et tu maiora mereris,

Quumque sit ipse bonus diligit ille bonos

Et te Petrus amat, nec tu non diligis ipsum.

Alter in alterius certat amore pio

Nec sine te uellet vitam traducere Petrus,

28 Keith Polk, "Foreign and Domestic in Italian Instrumental Music of the Fifteenth Century," in Musica Franca: Essays in Honor of Frank A. D'Accone, ed. Irene Alm, Alyson McLamore, and Colleen Reardon (Stuyvesant, NY: Pendragon Press, 1996), 323-32, at 327. Pietrobono's Italian roots have long been questioned in favor of the view that he was from northern Europe; see MacCarthy, "What's in a Name?," 4-11.

29 This figure should not be confused with one "Malacise da Firenze," a singer and viol player who appears in payments and correspondence in the $1450 \mathrm{~s}, 60 \mathrm{~s}$, and $70 \mathrm{~s}$ in Ferrara, Milan, and Mantua. Malagise (in northern Italy) or Malagigi (in Tuscany) was the Italian form for Maugis, a character in chivalric literature, and thus was a common nickname in this period. "Malacise" was the chosen nickname of several individuals at the court of Ferrara, possibly including the tenorista Francesco's uncle. I thank Andrea Canova for clarifying the distinction between regional spellings.

30 Brandolini, De laudibus Petriboni, lines 133-41; trans. in Blackburn, "The Foremost Lutenist," where the duo's instruments and performance practice are discussed at length. Such performing duos are depicted in the early sixteenth-century paintings of Giovanni Bellini in the Galleria dell' Accademia in Venice. 
Te quoque non absque hoc vivere posse putem.

Vos amor unus alit, claros ars reddidit una

Et tellus ne quid discrepet una dedit

Quid nam igitur dignum Francisce utroque precabor

Tu sibi et ille tibi vivat uterque diu. ${ }^{31}$

O singular companion of the Muses' famous nursling, sweet comrade in art, mighty leader in love, from where has the day so glad and so bright shone on you. Which god led you into so great a friendship? I know indeed; your mind, your vigorous strength led you, and the true love that can unite enemies. For by your virtues you too merit greater things, and since he himself is good, love loves good men, and Pietro loves you, and you hold him dear. Each vies the other in faithful love, Pietro does not wish to pass through this life without you; likewise, I should think you unable to live without him. One love nourishes you both, one art renders you famous, and one land has granted that there should be no disagreement. What therefore, Francesco, shall I pray for that is worthy of you both? May each of you live long, you for him and he for you. ${ }^{32}$

Their travels together on an Este-sponsored diplomatic mission to England just a few years before these verses were penned would have certainly helped to strengthen that friendship.

Taken as a whole, this notarial document adds to the picture of Pietrobono's life, his status, his colleagues, and his experiences within Borso d'Este's court familia, a body that included secretaries, chancellors, officials of the Este casa, chaplains, barbers, and musicians. ${ }^{33}$ Many of the witnesses to this will and Pietrobono's estate executors were also part of this social world, accessing courtly life at a level more intimate than most courtiers. It is thus clear that the court furthered its own diplomatic agenda by making use of Pietrobono's talents. Having examined the contents of the will and its signatories, let us return to its original purpose: a hedge against a risky voyage "ad partes Anglie."

\section{The Journey from Ferrara to England}

By the mid-1460s relations between Ferrara and England were fairly stable. Gifts and favors had been exchanged between the two courts starting in

31 Aurelio Brandolini, Ad Franciscum Petriboni comitem, Lucca, Biblioteca Capitolare Ms 525 , fols. $182 \mathrm{v}-183 \mathrm{r}$; ed. Tommaso de Marinis, La biblioteca napoletana dei re d'Aragona, 4 vols. (Milan: Hoepli, 1947-52), 1:76.

32 I thank Leofranc Holford-Strevens for his generous improvements to my translation.

${ }^{33}$ Guido Guerzoni, "Familia, Corte, Casa e Stato. Alcune precisazioni sul caso estense tra Quattro e Cinquecento," in Il ruolo economico della famiglia, ed. Guido Alfani (Rome: Bulzoni, 2007), 213-33. 
the 1440 s, under the reigns of Leonello d'Este and Henry VI. ${ }^{34}$ English musicians visited Ferrara. And English music, both sacred and secular, was copied into manuscripts circulating there. ${ }^{35}$ A number of English students and nobles were copying and purchasing books in Ferrara, taking degrees at the Ferrarese studio; a few even took in lectures by the humanistic scholars Guarino da Verona (1374-1460), Theodorus Gaza (ca. 1398-ca. 1475), Guarino's son Battista (1434-1513), and Ludovico Carbone (1430-85). ${ }^{36}$ The sculptor Domenico di Paris ( $f$. 1443-1501), who had produced major public and court monuments and sculptures in Ferrara, was commissioned in 1457 by "un nobelle de Ingletera" to produce an artwork. ${ }^{37}$

34 Rawdon Brown, ed., Calendar of State Papers Relating to English Affairs in the Archives of Venice, vol. 6, 1555-1558 (London: Her Majesty's Stationery Office, 1877), vii-lxiii; Luciano Chiappini, "Le relazioni tra Ferrara estense e Inghilterra nel '400 e nel '500," in The Renaissance in Ferrara and Its European Horizons, ed. June Salmons and Walter Moretti (Swansea: University of Wales Press, 1984), 175-89; and Lockwood, Music in Renaissance Ferrara, 62-68.

35 Nino Pirrotta, "Two Anglo-Italian Pieces in the Manuscript Porto 714," in Speculum Musicae Artis. Festgabe für Heinrich Husmann zum 60. Geburtstag am 16. Dezember 1968, ed. Heinz Becker and Reinhard Gerlach (Munich: Wilhelm Fink, 1970), 253-61; Reinhard Strohm, The Rise of European Music, 1380-1500 (Cambridge: Cambridge University Press, 1993), 264-66, 392-93; James Haar and John Nádas, "The Medici, the Signoria, the Pope: Sacred Polyphony in Florence, 1432-1448," Recercare 20 (2008): 25-93, esp. 74-84; Evan A. MacCarthy, "Music and Learning in Early Renaissance Ferrara, c. 1430-1470" (Ph.D. diss., Harvard University, 2010), 13-14, 18-20; and Fallows, ed., Secular Polyphony, 1380-1480.

36 Several of these students later served the English crown. John Gunthorpe, who had studied with Battista Guarini senior in Ferrara, returned to England to become secretary and chaplain to Queen Elizabeth, wife of Edward IV, then chaplain to Edward IV (by 6 August 1466), and in later years Keeper of the Privy Seal and Dean of Wells Cathedral. On English students in Ferrara, see Giuseppe Pardi, Titoli dottorali conferiti dallo studio di Ferrara nei sec. XV e XVI (Lucca: Marchi, 1901; facs. ed., Bologna: Forni, 1970); Rosamund J. Mitchell, "English Students at Ferrara in the XV. Century," Italian Studies 1 (1937): 75-82; idem, John Tiptoft (1427-1470) (London and New York: Longmans, Green, 1938); idem, "English Student Life in Early Renaissance Italy," Italian Studies 7 (1952): 62-81; idem, John Free: From Bristol to Rome in the Fifteenth Century (London: Longmans, Green, 1955); Barry Collett, "Universities, Governments, and Reform: English Students at Ferrara During the Fifteenth and Sixteenth Centuries," in Alla corte degli Estensi: Filosofia e cultura a Ferrara nei secoli XV e XVI. Atti del convegno internazionale di studi, Ferrara 5-7 Marzo 1992, ed. Marco Bertuzzi (Ferrara: Università degli studi di Ferrara, 1994), 125-46; Sears Jayne, Plato in Renaissance England (Dordrecht: Kluwer, 1995), 19-20; Cecil H. Clough, "Late Fifteenth-Century English Monarchs Subject to Italian Renaissance Influences," in England and the Continent in the Middle Ages: Studies in Memory of Andrew Martindale; Proceedings of the 1996 Harlaxton Symposium, ed. John G. Mitchell (Stamford: Shaun Tyas, 2000), 298-317, at 311; Cecil H. Clough, "Gunthorpe, John (d. 1498)," Oxford Dictionary of National Biography, (Oxford University Press, 2011), https://doi.org/10.1093/ref:odnb/11752 (accessed 31 August 2017). See also the editor's introduction in Roberto Weiss, Humanism in England During the Fifteenth Century, ed. David Rundle and Anthony John Lappin, 4th ed. (Oxford: Society for the Study of Medieval Languages and Literature, 2010), vi-xliv; and Daniel Wakelin, "England: Humanism Beyond Weiss," in Humanism in Fifteenth-Century Europe, ed. David Rundle (Oxford: The Society for the Study of Medieval Languages and Literature, 2012), 307-36.

37 For this payment see Ferrara, Archivio di Stato, Archivio Storico del Municipio di Ferrara, Serie finanziaria, Sec. XV, busta 2, "Zornale" 1457, fol. 38v; transcribed in Franceschini, Artisti a Ferrara, 1:469 (\#798). 
Attempts had even been made by the Englishman John Tiptoft to lure Ferrarese scholars back to England with him, as we learn from an oration and poem by Carbone. Before Tiptoft's return from Italy to England in late summer 1461 to work for the newly crowned Edward IV, Carbone stated in December 1460 that he had been invited by Tiptoft to leave Ferrara: "Namely influenced by some favorable opinion about my talent (I do not know how), [Tiptoft] has wished to take me with him to England, to which I am willing and yielding surely, now if only the Ferrarese will be unpleasant to me." ${ }^{38}$ This is the Tiptoft mentioned above, who in 1460 had arranged for the sending of a collection of songs from Venice or Padua to Giovanni de' Medici. ${ }^{39}$ By 1463 Tiptoft was a Knight of the Garter, lord steward of the royal household, and serving the Crown on a number of diplomatic missions. Ferrarese interests had also been represented in England via diplomatic channels with Leonello d'Este's natural son Francesco d'Este (ca. 1430-after ca. 1475), who spent most of his life at the Burgundian court, and who in 1463 served as escort to Margaret of Anjou on her visit to Bruges. ${ }^{40}$

A wide array of archival documents convincingly demonstrates that Pietrobono's voyage to England was an already planned mission organized by Borso d'Este. In the 1460s the Este court developed a new interest that persisted for the rest of Borso's life and continued under his brother Ercole's rule: English horses. It is well documented that Borso d'Este spared no expense when it came to buying horses. Military might, ceremonial spectacles, and the mundane reality of agriculture and transportation required horses of all kinds. In 1462, 1464, and 1468 Borso organized jousting tournaments at Ferrara, modeled on those held in Burgundy and France. ${ }^{41}$ Borso also established a palio in Ferrara in 1467, honoring a visit by Filippo Maria Sforza with

38 See Mitchell, John Tiptoft (1427-1470), 79; Roberto Weiss, "John Tiptoft, Earl of Worcester, and Ludovico Carbone," Rinascimento 8 (1957): 209-12, at 211n4; and Blackburn, "'The Foremost Lutenist in the World." In his funeral oration for Guarino of Verona, Carbone observed that Tiptoft "despoiled the libraries of Italy so he might adorn England with handsome monuments of books." Roberto Weiss, "The Library of John Tiptoft, Earl of Worcester," Bodleian Quarterly Record 8 (1937): 157-64, at 157; and Benjamin G. Kohl, "Tiptoft, John, First Earl of Worcester (1427-1470)," in Oxford Dictionary of National Biography (Oxford University Press, 2015) http://www.oxforddnb.com/view/10.1093/ref:odnb/ 9780198614128.001.0001/odnb-9780198614128-e-27471 (accessed 31 August 2017).

39 See note 12.

40 Ernst Kantorowicz, "The Este Portrait by Roger van der Weyden," Journal of the Warburg and Courtauld Institutes 3 (1940): 165-80, at 172; Richard J. Walsh, Charles the Bold and Italy (1467-1477): Politics and Personnel (Liverpool: Liverpool University Press, 2005), 281-91; and MacCarthy, "Music and Learning in Early Renaissance Ferrara, c. 1430-1470," 201-3.

41 On the joust tournaments at Ferrara, see Thomas Jason Tuohy, Herculean Ferrara: Ercole D'este (1471-1505) and the Invention of a Ducal Capital (Cambridge: Cambridge University Press, 2002), 237, 250-56. 
Figure 3. Francesco del Cossa (1435-78), The Palio of San Giorgio, detail from the month of April fresco in Salone dei Mesi of Palazzo Schifanoia, Ferrara. Late 1460s. Photo: Scala/Art Resource, NY

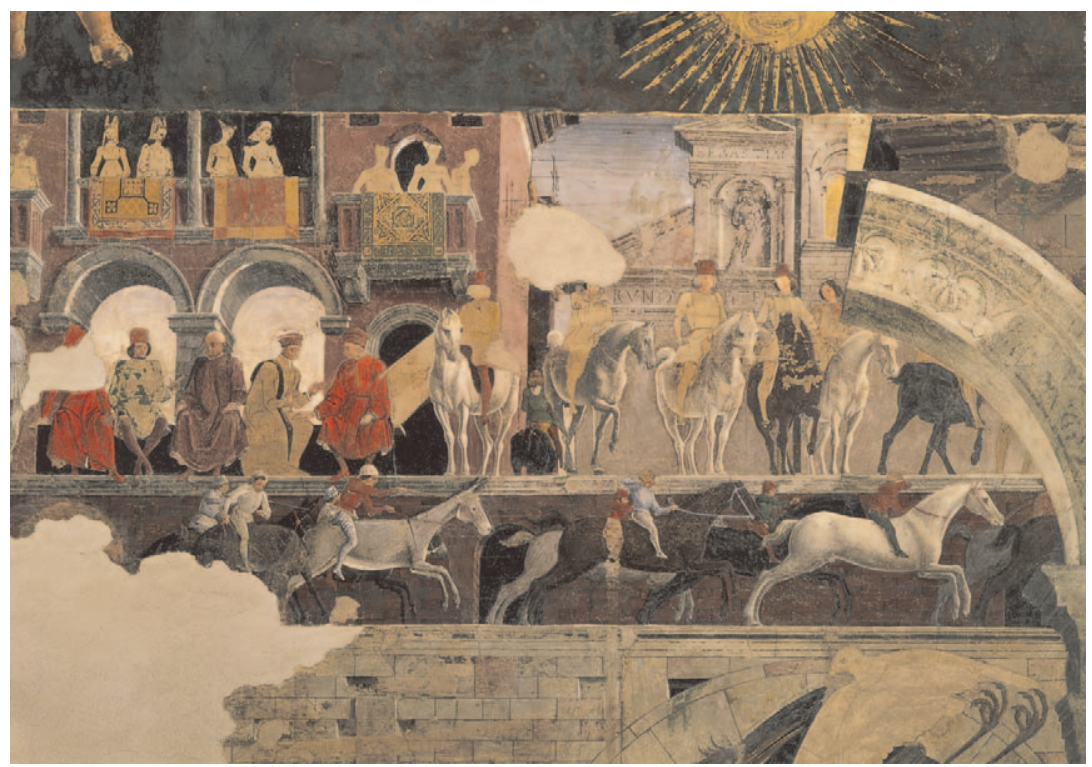

horseracing, and sent his horses to compete in races elsewhere in Italy. ${ }^{42}$ The excitement and political importance of Borso's Ferrarese palio was captured in the zodiacal fresco cycle of the Palazzo Schifanoia's Salone dei Mesi, painted in the late 1460 s, a cycle also known for its depiction of musical instruments and music-making. ${ }^{43}$ Figure 3 shows Borso d'Este astride a horse, viewing the race in progress.

${ }^{42}$ In April 1466 a palio was also run, as it is today, in honor of the feast of San Giorgio, the city's patron saint. Borso's racehorses competed in Florence, Mantua, Bologna, Parma, Brescia, and Padua. See Thomas Jason Tuohy, "Studies of Domestic Expenditure at the Court of Ferrara 1451-1505: Artistic Patronage and Princely Magnificence" (Ph.D. diss., University of London, 1982), 187-89; idem, Herculean Ferrara, 34, 241. On 7 August 1466 a Dominican friar was paid $12 £ 16$ s by the Este court for copying "uno libro de remedii de cavalli" for Borso. Additionally, two veterinary manuscripts with texts concerning the care of horses, produced in southern Italy in the early fifteenth century, were either owned by the Este court's master of the stables under Alfonso I d'Este (Giovanni Maria della Salla) or later entered the Biblioteca Estense in Modena: respectively, New York, J. Pierpont Morgan Library, Ms M.735; Modena, Biblioteca Estense, Ms $\alpha$.J.3.13 (It. 464).

${ }_{43}$ The frescoes for the month of April depict both the palio of San Giorgio and the triumph of Venus. On the entire cycle in the Salone dei Mesi of the Palazzo Schifanoia, see Salvatore Settis and Walter Cupperi, eds., Il Palazzo Schifanoia a Ferrara = the Palazzo Schifanoia in Ferrara, 2 vols. (Modena: F. C. Panini, 2007); and Ranieri Varese, "Gli affreschi di 
To compete in a palio at the highest level, stable masters and courtiers across the Italian peninsula sought out the fastest breeds from North Africa, Turkey, and elsewhere: the Barberi, the Cavalli Turchi, and the Irish Ubini (hobby horse). ${ }^{44}$ The hobby horse, often bred at the royal stud in Ireland, was especially sought after for its excellent sprinting abilities; as such it was well-suited for the short-distance Italian palio races. ${ }^{45}$ The hobby horse thus often became a part of diplomatic gift exchanges with the English. In fact, in the late 1440s Leonello d'Este was given an "ambling hobby" by Henry VI and his wife, Queen Margaret of Anjou, as thanks for the "honorable and liberal treatment" provided to the visiting university student Reynold Chichele. ${ }^{46}$ In 1466 a hobby horse was presented to Borso d'Este at Fossadalbaro, an Estense country palace on the Po Grande not far from Ferrara, by a servant of "that magnificent lady related to the King of England."

Starting in the 1450s, Borso sent agents to Hungary, France, Sicily, Tunisia, Spain, and still further afield to find the highest-quality horses for the Este court stables. ${ }^{48}$ This important pursuit also took Estensi agents to England and Ireland. One such agent was Biagio da Birago, master of the court stables in Ferrara for much of the second half of the fifteenth century, whom Borso sent several times to purchase swift English horses. This is the same Biagio da Birago who appeared as the first witness for Pietrobono's testament. ${ }^{49}$

Palazzo Schifanoia," in Un rinascimento singolare: la corte degli Este a Ferrara, ed. Jadranka Bentini and Grazia Agostini (Milan: Silvana, 2003), 105-8.

44 On the acquisition of foreign horse breeds, see Elizabeth Tobey, "The Palio Horse in Renaissance and Early Modern Italy," in The Culture of the Horse: Status, Discipline, and Identity in the Early Modern World, ed. Karen Raber and Treva J. Tucker (New York: Palgrave Macmillan, 2005), 63-90, esp. 67-68; and Andrea Tonni, "The Renaissance Studs of the Gonzagas of Mantua," in The Horse as Cultural Icon: The Real and the Symbolic Horse in the Early Modern World, ed. Peter Edwards, Karl A.E. Enenkel, and Elspeth Graham (Leiden and Boston: Brill, 2012), 261-78.

45 Tobey, "The Palio Horse," 70-71.

46 Modena, Archivio di Stato, Archivio Segreto Estense, Estero, Carteggio di principi e signorie fuori d'Italia, Inghilterra, Busta 1608/I. Chichele later became rector of the university in Ferrara. Letters of Henry VI to Leonello d'Este (10 May 1447; 29 November 1449); of Margaret of Anjou to the marchesa di Ferrara, Maria d'Aragona (27 November 1445); and Margaret of Anjou to Leonello (10 May 1446/47). This exchange is discussed in Lockwood, Music in Renaissance Ferrara, 63-64; and Chiappini, "Le relazioni tra Ferrara estense e Inghilterra," 177. The Gonzagas purchased or received as gifts hobby horses from Henry VIII; see Tobey, "The Palio Horse," 75; and Carlo Cavriani, Le razze Gonzagesche dei cavalli nel mantovano e la loro influenza sul puro sangue inglese (Mantua: Adalberto Sartori, 1974), 15-22, 26-30.

47 Modena, Archivio di Stato, Camera Ducale Estense, Amministrazione dei prinicipi b. 14, 1466, fol. 46v. The identity of which relative of Edward IV was visiting the court of the Este remains uncertain, but this palace had also been visited by the queen of Cyprus, Emperor Frederick III, and other dignitaries in the fifteenth century. See Tuohy, Herculean Ferrara, 363.

48 Luigi Alberto Gandini, "Viaggi, cavalli, bardature e stalle degli Estensi nel Quattrocento: studio storico," Atti e memorie della R. Deputazione di storia patria per le Provincie di Romagna ser. 3, vol. 10 (1892): 41-94, esp. 75-79.

49 Biagio was also sent to other Italian courts to purchase saddles and horse collars for the Este family members. A 1465 trip to Mantua is cited in ibid., 53. 
Court-sponsored horse-trading missions from Ferrara to England are documented in archival records for the years 1466, 1470, 1479, and $1498 .^{50}$ Letters from Biagio da Birago, while traveling in the 1470 s and later, illuminate his central role in negotiations for the finest horses, arranging meetings with Edward IV or Henry VII himself. ${ }^{51}$ Some of these letters also reveal that crossing the English Channel, particularly in a boat carrying horses, was a dangerous feat in the fifteenth century, with regular threats of war, pirates, and foul weather. ${ }^{52}$

For Pietrobono's August 1466 departure, the one referenced in his will, we have neither surviving diplomatic letters from Biagio nor official instructions from the court. In their absence we find a dozen payments from June, July, and August 1466 for gifts to Edward IV, to be carried to England by Biagio: two lavish gold sopraveste for horses designed by the tailor Nicolò da San Severino, along with two horses (breed unspecified) and "altre cose." 53 The coverings were to be as radiant as possible, studded with luminous nails, buckles, bolts, and bosses, to which painters applied gesso, silver, and gold. A contemporary Italian drawing of such a decorated horse cover can be found in a fifteenth-century copy of the widely circulated Practica de morbi naturali et accidentali, segni e cure de cavalli (fig. 4). ${ }^{54}$

50 Alessandro Giuseppe Spinelli, Quattro Documenti Anglo-Estensi del Secolo XV. pubblicati per le nozze Bruni-Fox (Modena: A. Rossi, 1894); and Chiappini, "Le relazioni tra Ferrara estense e Inghilterra," 175-76.

51 While visiting Bruges on behalf of the Este court in 1471, Biagio was sought by the Sforza court to intercede with Burgundian officials on behalf of a Milanese ambassador who had been arrested while attempting to make the voyage to England on an official visit to recently restored Henry VI; see Walsh, Charles the Bold and Italy, 165. In the early sixteenth century, Alberto d'Este arranged to have a fine horse sent to Henry VIII along with gifts of gold, falcons, and a leopard, all with the hopes of Henry VIII convincing Pope Leo X to restore Modena and Reggio to the Duke of Ferrara; see Sarah Duncan, "The Stables of the Italian Renaissance Courts and Theories of Stable Management” (Ph.D. diss., Queen Mary, University of London, 2013), 32.

52 Richard W. Unger, "Ships and Sailing Routes in Maritime Trade around Europe 1300-1600," in The Routledge Handbook of Maritime Trade around Europe 1300-1600: Commercial Networks and Urban Autonomy, ed. Wim Blockmans, Mikhail Krom, and Justyna WubsMrozewicz (Abingdon: Routledge, 2017), 17-35; Lillian Ray Martin, "Horse and Cargo Handling on Medieval Mediterranean Ships," International Journal of Nautical Archaeology 31 (2002): 237-47; and Jean Verdon, Travel in the Middle Ages, trans. George Holoch (Notre Dame: University of Notre Dame, 2003), 63-65, 79.

53 Modena, Archivio di Stato, Camera Ducale Estense, Guardaroba 88, fol. 59; transcribed and discussed in Tuohy, "Studies of Domestic Expenditure," 215-18; idem, Herculean Ferrara, 257n134: “. . p per fattura de due sopraveste da cavallo, una de panno d'oro crimisino rizudo e l'altra de dalmaschino crimisino brocado d'oro; le quale sopraveste ciascuna è cum la testiera, pectorale e cuperto de drieto afrapade cum fraponi grande afoie, cum franze de oro e de seda verde intorno a dicti fraponi dopie, cioè da la lato drito e roverso, et ale orechie, ochi e naso e cum uno franzone grosso de più franze elta d'oro e de seda verde che va suso il colo. Fodrate una de tafeta verde solamente che è quella de pano d'oro rizudo, l'altra fodrata de tella aretino il drapo e de dicta tafeta sopra la tella. Li quali cuperti fe far lo Illmo. N.S. per mandare a donare insieme a dui cavalli et altre cose per Biasio de Birago ala Maiestà del Re de Inghilterra." Each sopravesta cost more than $£ 800$.

54 Modena, Biblioteca Estense, Ms $\alpha . J .3 .13$ (It. 464), fol. 12r. 
FIGURE 4. Practica de morbi naturali et accidentali, segni e cure de cavalli. Modena, Biblioteca Estense, Ms $\alpha$.J.3.13 (It. 464), fol. 12r, detail. Reproduced with permission from the Ministero dei Beni e delle Attività Culturali e del Turismo. Gallerie Estensi, Biblioteca Estense Universitaria

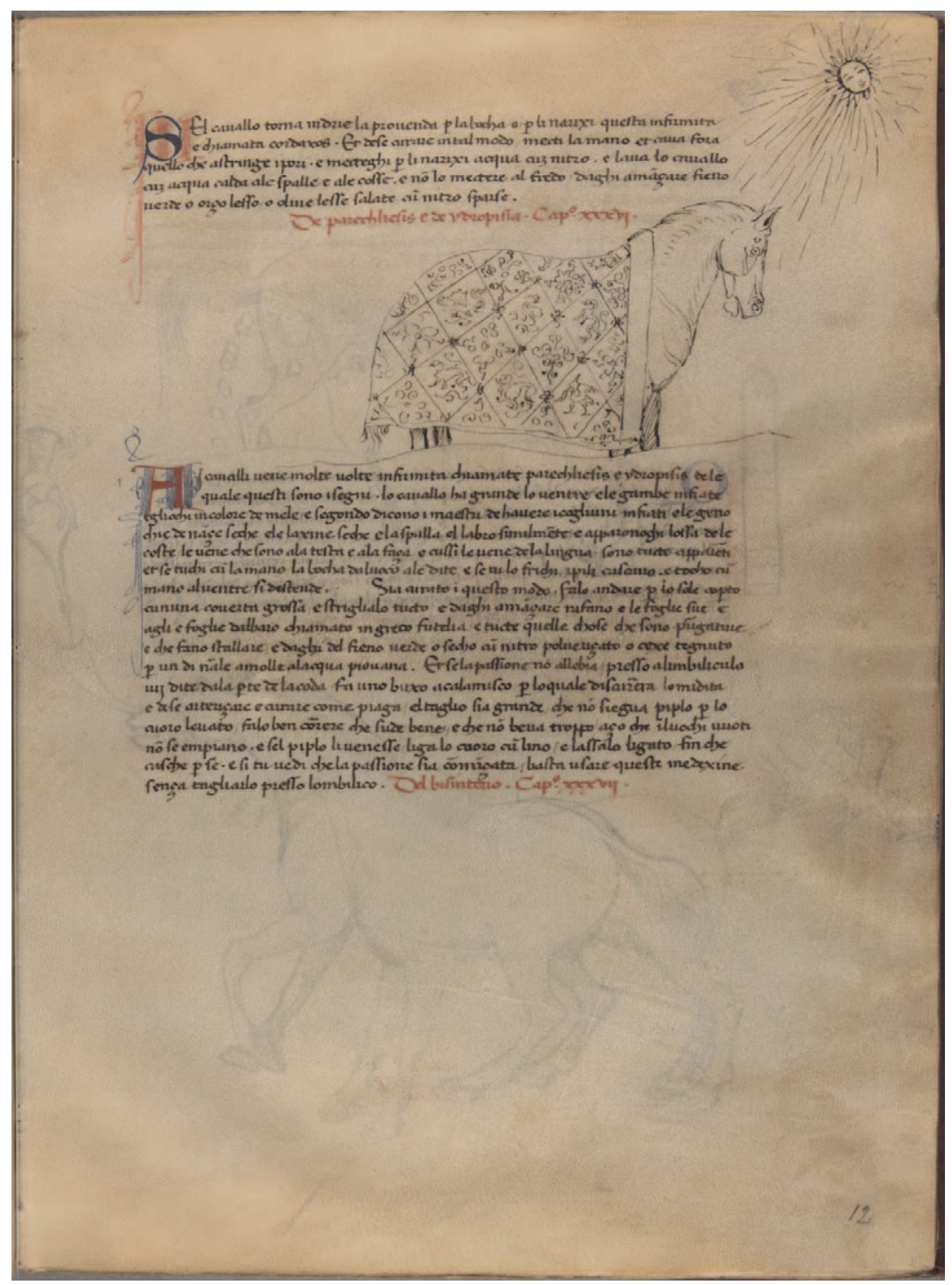


In addition to the tailor's remuneration, payments to Biagio totaling more than 250 gold ducats are marked "for going to England to present [gifts] to the King and for purchasing horses. ${ }^{\circ 5}$ Two additional documents from summer 1466 confirm that Pietrobono and his tenorista Francesco were preparing for the voyage. On 26 July, an entry in the Camera Ducale's Mandati shows Francesco putting in order his debts "for this journey with Pietrobono to England." ${ }^{56}$ Two weeks later, on 10 August, just two days before the will was notarized, another entry in the same volume of the Mandati records that debts are to be paid since "Pietrobono dal Chitarino ... is going now to England. ${ }^{, 57}$ Debts were paid and the estate was settled; a will was drafted, witnessed by friends and traveling companions, and notarized. Pietrobono and his tenorista were heading north. ${ }^{58}$

Perhaps coincidentally, this August 1466 departure to make direct contact with the English Crown and purchase new English horses occurred nearly simultaneously with Borso d'Este's cooperation with the Florentine Luca Pitti in the plot to overthrow the Medici in Florence, in support of which Borso had sent a cavalry of 1,300 toward Florence. Weeks later these soldiers were scattered when word broke that the

55 The payment from the Registri della Camera Ducale is cited in Spinelli, Quattro Documenti Anglo-Estensi, 6. Several payments made to Biagio for this mission appear in Modena, Archivio di Stato, Camera Ducale Estense, Amministrazione dei prinicipi b. 14, 1466. A horse handler named Cichino da Milano was also paid for accompanying Biagio on the journey. Ibid., fol. 36v.

56 Modena, Archivio di Stato, Camera Ducale Estense, Mandati in volume 12, 1466, fol. 168r: "26 July 1466. B[orsius] Dux. Ala Ill[ustrissi]ma du[x] S[ignoria] V[ostra] Supplica humilmente il fidele servitore de quella, Francesco tenorista de Piedrobon del Chitarino che la vostra du. S. se digni per sua solita liberalitate et gratia donarli ducati vinticinque doro per potere metterse in ordine per questa sua andata cum piedrobon in Ingilterra et pagare li suoi debiti et fare honore in questa andata ala vostra no ${ }^{\text {ta }}$ signoria ala quale continue se recomanda, Et piu non li dara impazo ni tedio alcuno de simile cagione. Ill.mus dominus noster dux etc. Mandat. factoribus generalibus Quod dare fatiant Supplicante libras vigintiquinque q. per viam condemnationis camere de dono et liberalitate solita sue Cel. Victorius de pavonibus scripsit xxvj Julij 1466.” I am grateful to Camilla Cavicchi and Bonnie Blackburn for sharing images and transcriptions of this document and those cited in the next note.

57 Modena, Archivio di Stato, Camera Ducale Estense, Mandati in volume 12, 1466, fol. 180r: "10 August 1466, Ferrara. Borsius dux etc. Dilectissimi nostri. Piedrobono dal Chytarino che hora va in Engelterra debe dare ala camera L. cento oltra quello altro suo debito che Noi ordinassemo se dovesse retenerli L. cinquanta ala volta Come debe apparere/Volemo che mettiate queste L. cento cum quelle altre et faciativi tuto uno corpo non lo gravando altramente et non li retenendo de tuto sono cinquanta libr. ala volta come era ordinato per lo primo debito. Belriguardi X augusti 1466." Additional court documents from 1466, usually payments concerning Pietrobono, appear on 9 April, 24 May, 5 July, 10 July, 30 July, 5 November, 19 November, 17 December, and 19 December. One entry, dated 12 August, indicates that Pietrobono received money worth 67 small casks of wine. Whether this wine was intended for the journey is unclear.

58 In Pietrobono's testament, the phrase "ad partes Anglie" could of course mean traveling to lands now in France, but if, as seems likely, he were accompanying Biagio with royal gifts, and taking into account the references to England in the court records, then they were probably headed to London, Westminster, or Windsor. 
Sforza had sent their own forces to defend the Medici. ${ }^{59}$ Francesco Sforza had died in March of the same year; two letters from Borso's nephew Francesco d'Este, sent from Bruges and Brussels in spring 1466, offered updates on the affairs between Burgundy and England. ${ }^{60}$ These political and military developments must have encouraged Borso to prepare an embassy at a moment when both Burgundian and French ambassadors eagerly sought alliances with England.

An English chronicle notes the presence of "inbassytors com from the Conte de Ferare" in early $1467 .{ }^{61}$ And Este court documents point to the return of at least Biagio da Birago in April of that year. Whether Pietrobono remained in England, travelled elsewhere, or returned after a few weeks or months is uncertain, especially since there are payments to him from the Este court in November and December, but not again until the following July. ${ }^{62}$ If he remained in England until the late spring, he could have witnessed the celebrated tournament at Smithfield in June 1467 between Anthony, Bastard of Burgundy (1421-1504), and Anthony Woodville, Lord Scales and later second Earl Rivers (ca. 1440-83). ${ }^{63}$

This tournament had been in the works for some time. Anthony accepted Woodville's challenge to joust; after military delays and weather problems, Anthony finally arrived in England with his retinue, which included the Burgundian chronicler Olivier de la Marche. It was in the

59 At Imola Ferrarese agents encountered Milanese soldiers who were ready to proceed to Florence in support of Piero de' Medici. On this plot and Borso's involvement, see Nicolai Rubinstein, The Government of Florence under the Medici (1434 to 1494) (Oxford: Clarendon Press, 1966), 153-83; and Paula Clarke, "A Sienese Note on 1466," in Florence and Italy: Renaissance Studies in Honour of Nicolai Rubinstein, ed. Peter Denley and Caroline Elam (London: Committee for Medieval Studies, Westfield College, 1988), 43-52, at 45.

In the same month Borso sent organ builders to Milan to supervise the organ construction in the duomo there; see Enrico Peverada, "Un organo per Leonello D'este," L'Organo: rivista di cultura organaria e organistica 28 (1993-94): 3-30, at 28.

60 Modena, Archivio di Stato, Archivio Segreto Estense, Principati non regnanti 130, 20 March 1466 (Brussels) and 6 May 1466 (Bruges), Francesco d'Este to Borso d'Este. See Walsh, Charles the Bold and Italy, 283.

61 James Gairdner, ed., "Chronicle of William Gregory, Skinner," The Historical Collections of a Citizen of London in the Fifteenth Century (London: Camden Society, 1876), 55-239, at 235 .

62 The sounds of plucked strings continued at the court in Ferrara in Pietrobono's absence, as evidenced by the gift of money from Borso to "Antonio sonatore del chitarino," who visited the court from Bergamo in October with the condottiere Bartolomeo Colleoni, and for whom festivities were arranged in the Palazzo del Corte's Sala dei Piffari. See Modena, Archivio di Stato, Camera Ducale Estense, Amministrazione dei prinicipi b. 14, 1466, fol. 50r; and Tuohy, Herculean Ferrara, 59.

63 Sydney Anglo, "Anglo-Burgundian Feats of Arms: Smithfield, June 1467," Guildhall Miscellany 2 (1965): 271-83; and Mario Damen, "Tournament Culture in the Low Countries and England," in Contact and Exchange in Later Medieval Europe: Essays in Honour of Malcolm Vale, ed. Hannah Skoda, Patrick Lantschner, and R.L.J. Shaw (Woodbridge: Boydell, 2012), 247-65, at 263-65. Woodville was the brother-in-law of Edward IV and, as David Fallows kindly shared with me, the author of the poem Somewhat musing, later set to music by Robert Fayrfax. 
midst of this grand occasion that the marriage agreement between Charles of Charolais (1433-77) and Margaret of York (1446-1503) appears to have been formalized. ${ }^{64}$ Before the tournament was cut short by the death of Charles's father, Philip the Good (1396-1467), a chronicler observed the music performed at a banquet for Edward IV, his wife, and Anthony the Bastard, especially the presence of twelve musicians playing lutes and gitterns:

Quant le Roy, la Royne, Monseigneur le bastard, et toute la compagnie furent venuz, en tant quon dressa la viande, le Roy les mena au Jardin, qui estoit merueilleuseme[n]t plaisant. La commenca la dance, le Roy danca, et la Royne, et tous les aultres a tour. Sy auoit au milieu du parc, ou lon dancoit vne maisonette faicte denglent[ier], ou estoyent sonneurs de doussainnes qui Jouoyent tresmelodieusement, auec lutz et guisternes.

When the King, the Queen, my lord the Bastard, and all the company had come, and when the meal had been finished, the King led them into the garden which was marvellously pleasant. The dance began there. The King danced, and the Queen, and all the others in their turn. Also there was constructed in the middle of the park where they danced a maisonette made of briar where doussaine [dulcian/curtal] players were enclosed who played very melodiously with lutes and gitterns. ${ }^{65}$

In a similar vein, visitors to the English court from Eastern Europe in the first part of 1466 described hearing "a great company of trumpeters, pipers, and players of stringed instruments." 66

\section{Diplomacy and Musical Exchanges}

Christopher Page, Richard Rastall, Matthew Spring, and others have demonstrated the growing interest in plucked instruments like the lute

${ }^{64}$ On the secret treaty of "amity and mutual assistance," resolved 23 October 1466 between Edward IV and Charles of Charolais, see Charles Ross, Edward IV (New Haven and London: Yale University Press, 1997), 107-8.

${ }^{65}$ Ralph D. Moffat, "The Medieval Tournament: Chivalry, Heraldry and Reality: An Edition and Analysis of Three Fifteenth-Century Tournament Manuscripts" (Ph.D. diss., University of Leeds, 2010), 189-90, 325-26.

66 The account of the February 1466 visit is translated in Malcolm Letts, ed., The Travels of Leo of Rozmital through Germany, Flanders, England, France, Spain, Portugal and Italy 1465-1467 (Cambridge: Cambridge University Press, 1957), 46-47. The diary notes that the king's choir numbered forty-two and sang excellently. See also Strohm, The Rise of European Music, 314. A.R. Myers, The Household of Edward IV: The Black Book and the Ordinance of 1478 (Manchester: Manchester University Press, 1959), 131-32, accounts for 13 minstrels, who use "trumpettes... shalmuse and small pipes" as well as others who are "strengmen." For a recent review of the surviving evidence of English court minstrels, see Richard Rastall, "The Minstrels and Trumpeters of Edward IV: Some Further Thoughts," Plainsong and Medieval Music 13 (2004): 163-69. 
and gittern in fifteenth-century England. ${ }^{67}$ Inventories, chronicles, wills, tax records, iconographic evidence, and texts on lute tunings document this development. With respect to the late-fifteenth century Tudor court, too, Theodor Dumitrescu has documented the presence of foreign lutenists, including Italian and French musicians. ${ }^{68}$ Among the most interesting sources concerning fifteenth-century English lute music is the account book of the wool merchant George Cely, which outlines his musical and dance studies in Calais with the professional harpist Thomas Rede in 1474-75, just eight years after Pietrobono probably passed through Calais on the way to England ${ }^{69}$ Cely's account book records his purchasing a "byll ffor to lerne to tevne the levte" (mostly likely a handwritten tutor for playing as well as tuning) for 3s. $6 \mathrm{~d}$., while also learning "xiiij davnsys and an horne pype on the levte" as well as several songs, for which several titles are provided (table 2). ${ }^{70}$

The list of songs Cely paid to learn from Rede includes English-, French-, and Italian-texted works, many of which survive as polyphonic songs. Examples include John Bedyngham's "Myn hertis lust" and "O rosa bella," copied into Italian sources in the 1460s and 1470s. Interestingly, Celys says that he has learned multiple versions of the same tunes: at least two versions of "O Freshest Flour" and three versions of "Of Such Complain." The account book also refers to many dance tunes, including a hornpipe and a basse danse. Might these songs and dances represent the music Pietrobono heard in England, in Calais, or along the way? Perhaps Pietrobono brought Bedyngham's "O rosa bella" with him from Ferrara, where it had just been copied into the Porto manuscript. ${ }^{71}$ "O rosa bella" turns up again in another musical lesson in 1483, when the

67 Christopher Page, "The 15th-Century Lute: New and Neglected Sources," Early Music 9 (1981): 11-21; George Richard Rastall, "Secular Musicians in Late Medieval England" (Ph.D. diss., University of Manchester, 1968); and Matthew Spring, The Lute in Britain: A History of the Instrument and Its Music (Oxford: Oxford University Press, 2001), 8-46.

68 Theodor Dumitrescu, The Early Tudor Court and International Musical Relations (Aldershot, UK, and Burlington, VT: Ashgate, 2007), 82-83, 231.

${ }^{69}$ Kew, The National Archives, C. 47/37/11, fols. 1-5. Alison Hanham, "The Musical Studies of a Fifteenth-Century Wool Merchant," Review of English Studies 8 (1957): 270-74, at 271; eadem, The Celys and Their World: An English Merchant Family of the Fifteenth Century (Cambridge: Cambridge University Press, 1985), 33-35; and Fallows, ed., Secular Polyphony, $1380-1480$.

70 Hanham, "The Musical Studies," 271; Page, "The 15th-Century Lute," 18; Hanham, The Celys and Their World, 33-35; and Spring, The Lute in Britain, 27-28.

71 While Bedyngham's presence in England is accounted for several times in the 1450 s before his death in 1459 or 1460 , there remains the possibility first suggested by Lockwood that Bedyngham was one of two English musicians named John who appeared in Ferrara in the late 1440s. See Lockwood, Music in Renaissance Ferrara, 126; and David Fallows, "Bedyngham, Johannes," in Grove Music Online. Oxford Music Online (Oxford University Press). 
THE JOURNAL OF MUSICOLOGY

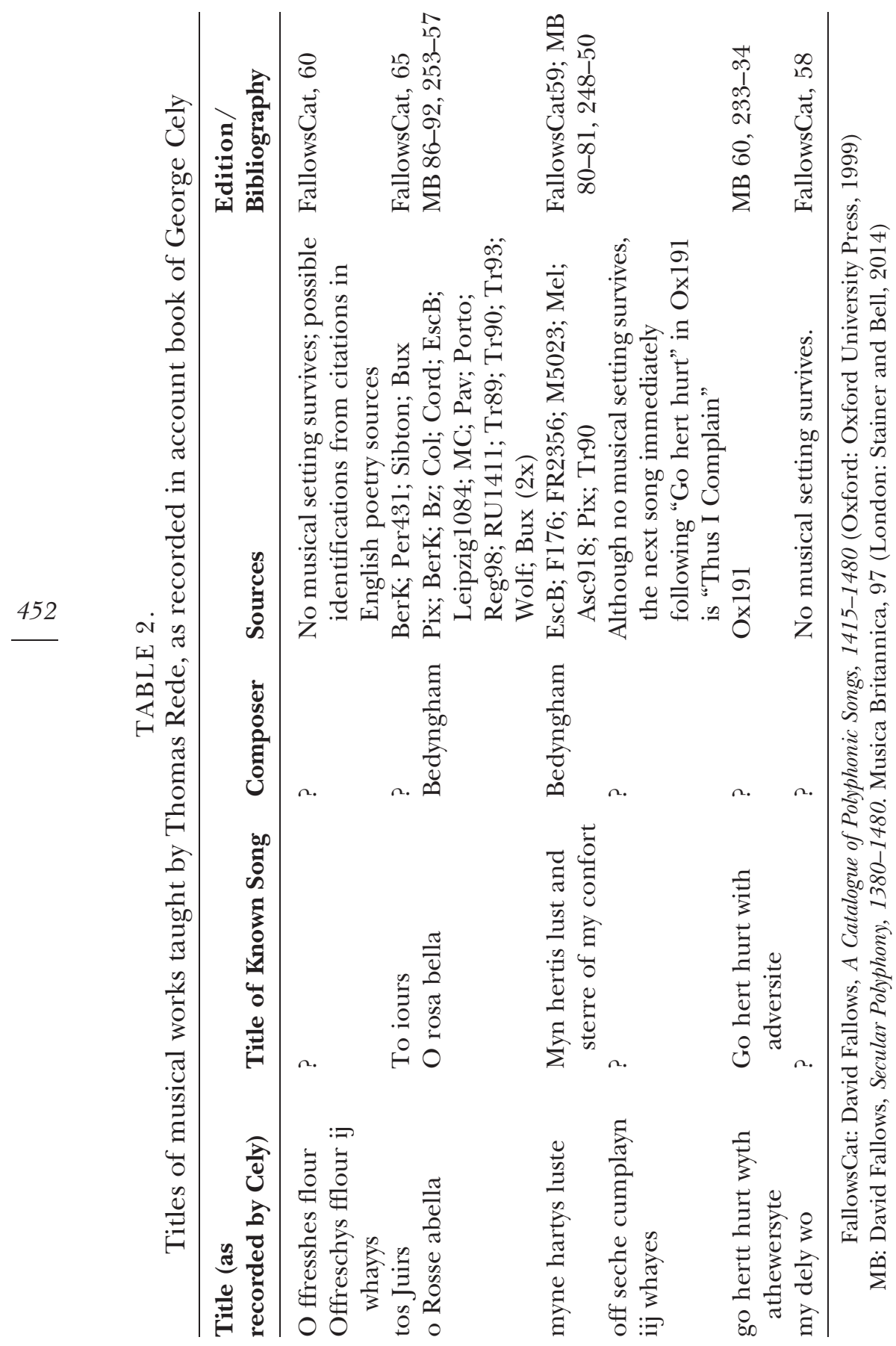


English musicians Conrad Smyth and Peter Skydell passed through Calais while journeying from Munich. ${ }^{72}$

Quite apart from the musical repertory Pietrobono might have encountered in England, a central question is just what Pietrobono's role on this voyage might have been. An April 1464 horse-trading mission to Tunisia may help elucidate this matter. A set of explicit instructions from Borso to Giovanni Giacomo della Torre includes a long list of gifts that were to be presented from the Este court to Uthman, the Hafsid, caliph of Tunisia (Ifriqiya), and his family. Among these gifts were straw hats, scissors, gloves for falconry, knives, wheels of cheese, dog collars, inkwells, chairs, a Murano glass table, two hunting horns, 200 bells, but most importantly "dui chitarini, cum molte corde et le sue casse" for the caliph's children. ${ }^{73}$ In exchange Borso's embassy received two lions and two ostriches, along with the horses they had come to purchase. Since there is evidence for Leonello d'Este presenting gifts of pipe organs to other leaders in Italy, it should not surprise us that gitterns and lutes also served as diplomatic gifts. ${ }^{74}$

If musical instruments were among the "altre cose" presented as gifts to Edward IV together with the two gilded horse sopraveste, might Pietrobono have been expected to offer musical instruction on these instruments, or at least a demonstration? Perhaps his celebrated reputation

72 James Matthew Cook, "Mid-Fifteenth-Century English Mass Cycles in Continental Sources" (Ph.D. diss., University of Nottingham, 2014), 40-41.

73 There are records of payment from the Este court to Biagio dal Chitarino on 6 March 1464 "per co[m] prare uno chitarino e corde a viniesia per la sua S[ignor] a" and on 4 May 1464 for purchasing two "chitarini...forniti de ogni cosa da Re." See Modena, Archivio di Stato, Amministrazione dei principi, b. 12, 1464, fol. 9r; and Modena, Archivio di Stato, Giornale del Camerlengo Rossetto, fol. 19 (1464). On this mission and the ordering of the lutes, see Cesare Foucard, Relazioni dei duchi di Ferrara e di Modena coi re di Tunisi. Cenni e documenti raccolti nell'archivio di Stato in Modena (Modena: Pizzolotti, 1881), 4, 16-18; Bonnie J. Blackburn, "Making Lutes in Quattrocento Venice: Nicolò Sconvelt and His German Colleagues," Recercare 27 (2015): 23-59, at 26-27; and Elizabeth Horodowich, "The Wider World: Foreigners, Travels, and Geography," in Italian Renaissance Diplomacy: A Sourcebook, ed. Monica Azzolini and Isabella Lazzarini (Toronto: Durham University and Pontifical Institute of Mediaeval Studies, 2017), 190-213, at 193-202. See also Isabella Lazzarini, Communication and Conflict: Italian Diplomacy in the Early Renaissance, 1350-1520 (Oxford and New York: Oxford University Press, 2015). On the Barberi horse breed, Italian trading with North Africa, and the 1460 gift of horses from Utman to Sigismondo Malatesta of Rimini, see Tobey, "The Palio Horse," 68-72. I offer sincere thanks to Tim McCall for sharing this set of instructions with me.

74 On the gift of a pipe organ from Leonello to Alfonso I of Naples, and on musical gifts in general, see Enrico Peverada, "Vita musicale nella Cattedrale di Ferrara nel Quattrocento: note e documenti," Rivista italiana di musicologia 15 (1980): 3-30, at 29; Lockwood, Music in Renaissance Ferrara, 135; A. F. C. Ryder, Alfonso the Magnanimous: King of Aragon, Naples, and Sicily, 1396-1458 (Oxford and New York: Clarendon Press, 1990), 33839; and Rob C. Wegman, "Musical Offerings in the Renaissance," Early Music 33 (2005): 425-37. 
preceded him, in which case his exceptional playing may have served an important diplomatic function, representing the magnificence of Borso's court to his English counterparts. In later years, Pietrobono's musical abilities were indeed deployed for diplomatic purposes: he traveled with Borso to Rome (1471) and Naples (1473), the latter as part of an official embassy of courtiers sent to bring Eleonora d'Aragona back to Ferrara for her marriage with Ercole d'Este. ${ }^{75}$ And after dinner on 28 August 1489, Pietrobono entertained an ambassador visiting Ferrara from the French royal court, whereupon the court chronicler described Pietrobono as "the foremost in the world at playing the lute" (il primo homo dil mondo di sonar liuto). ${ }^{76}$

Letters of credence and of safe conduct probably would have been carried by the Ferrarese envoys and their retinue as they crossed the Channel to England, protecting them and the gifts they carried. ${ }^{77}$ Upon arrival these visitors would most likely have been received at the court by Englishmen who had spent time in Ferrara. Two individuals who had studied in Ferrara and knew many of the same people as Pietrobono are John Tiptoft and John Gunthorpe. By 1466, Tiptoft was already Earl of Worcester, Knight of the Order of the Garter, and partially responsible for planning the tournament at Smithfield. Gunthorpe had recently been made chaplain to Edward IV, after serving as secretary and chaplain to Edward IV's wife Elizabeth. ${ }^{78}$ Other English connections specific to Pietrobono might have been through the composer and teacher Robertus de Anglia or the singer Anna, both of whom can be documented in Ferrara during the 1460 s. ${ }^{79}$

75 Lockwood, Music in Renaissance Ferrara, 112. For the trip to Rome, Borso d'Este brought 523 horses and 150 mules; the mules were either covered in cloths dyed in green, red, and white (Este colors) or, if they were carrying the personal items of Borso, covered in crimson velvet embroidered with the Este arms and carrying silver bells. See Giuseppe Pardi, ed., Diario ferrarese dall' anno 1409 sino al 1502 (Bologna: N. Zanichelli, 1928), 66-67. My thanks to Tim McCall for this reference.

76 Girolamo Ferrarini, Memoriale Estense: 1476-1489, ed. Primo Griguolo (Rovigo: Minelliana, 2006), 330: "A dì mercori 26 agosto uno ambasatore dil re di Franza arivò a Ferrara dopo hore 22, incontra al quale li andò lo duca nostro con la sua corte et con le trombe. Et intendo tal ambasatore va a Roma et a Napoli. Lo zobia proxima de sira, a dì 27 agosto, cenò con lo duca et lo veneri, a dì 28, doe cene cenò con lui facendolli grande honore, fazendoli dopo cena, la zobia, sonare Piedro Bono dal Chitarrino ferrarexe, primo homo dil mondo di sonar liuto, et altri musichi li fu anchora. A dì sabado 29 agosto, dicto ambasatore dil re di Franza se partì da Ferrara."

77 A safe-conduct letter from 1451 protecting Burgundian envoys on their way to England specifically guards the persons as well as their "lettres closes et patentes, instruccions, memoires, livres, escriptures." See Pierre Chaplais, English Diplomatic Practice in the Middle Ages, 2 vols. (London: H. M. Stationery Office, 1975), 1:325-27.

78 Examples of Gunthorpe's diplomatic orations and the influence of his exposure to humanistic Latin in Ferrara are found in ibid., 1:234-55.

79 For bibliographic references, see note 11 . The precise whereabouts of Robertus de Anglia between 1461, when he is documented as teaching music to the canons of the 
Italians stationed in the North would also have been effective at welcoming the Ferrarese envoy. A Lombard merchant working in Bruges, Lucchino della Chiesa, served as a contact for Biagio in 1470; in 1466 he had written to Borso in the role of informant for the Este court. ${ }^{80}$ More generally, Pietrobono and his traveling companions would have encountered entire communities of Italians in various neighborhoods in London, including merchants, grocers, and drapers. ${ }^{81}$ Pietrobono and his entourage would also have seen a great deal of England and English life beyond the court itself over the course of this diplomatic mission. A useful point of comparison, even though it took place several decades earlier, is a visit by Aragonese ambassadors to England in summer 1415. Expense records document travels over the course of two months to Winchester, Basingstoke, Hartfordbridge, Windsor, Brentford, London, Dartford, Rochester, Opsringe, Canterbury, Sittingbourne, Kingston, Guildford, Farnham, Alresford, Southwick, Alton, and Southampton. ${ }^{82}$

This English voyage was not Pietrobono's first and certainly not his last diplomatic mission: over the course of his life he also traveled on behalf of the Este court to Milan, Mantua, Rome, Naples, Rimini, Pesaro, and Hungary. Was he excited to travel these distances, see other parts of the world, and share his musical gifts? All we can say is that this dangerous voyage to England caused enough anxiety to lead him to draw up a will. It also appears that, by his later years, Pietrobono had grown tired of these missions, expressing no desire to travel to Hungary in the mid-1480s and thus forcing Beatrice d'Aragona to write from the court in Buda to her cousin Ercole and compel Pietrobono's visit. ${ }^{83}$

cathedral in Ferrara, and 1467, when he took over as magister cantus for the chapter at San Petronio in Bologna, remain uncertain. Given his return to England in 1474, the possibility of a visit in the mid-1460s cannot be ruled out.

${ }^{80}$ In the face of economic distress in England and growing anti-Italian resentment starting around 1440, merchants from Florence, Genoa, Lucca, and elsewhere were required to register with the English government and to provide detailed accounts of transactions to the Exchequer. On alien merchants working in England, see Helen Lesley Bradley, ed., The Views of the Hosts of Alien Merchants, 1440-1444 (London: Boydell Press, 2012); and Alwyn A. Ruddock, Italian Merchants and Shipping in Southampton: 1270-1600 (London: University College, 1951).

${ }^{81}$ Helen Lesley Bradley, "Italian Merchants in London, c1350-c1450" (Ph.D. diss., Royal Holloway and Bedford New College, University of London, 1992). In fact, in the late fourteenth century there were two Italian horse traders working in London: "John de Venys" and the Sienese "Mark de Ceretalo."

${ }_{82}$ Chaplais, English Diplomatic Practice, 2:828-29.

83 Emile Haraszati, "Pierre Bono luthiste de Mathias Corvin," Revue de Musicologie 31 (1949): 73-85, at 79-81; and Lockwood, Music in Renaissance Ferrara, 112-13. A will and testament for this Hungarian voyage has not yet surfaced in the archives. 
The most tantalizing aspect of Pietrobono's voyage to England is the possibility that he served as a conduit for the exchange of English and Italian music between England and Italy, that he facilitated the transmission of Italian and English lute styles, and that he shared Italian and English instruments. His will and testament provides new insight into the world of an unusually cosmopolitan musician and the lives of his family and fellow musicians; the expedition itself helps corroborate Brandolini's praise of Pietrobono as a marvel of the world. The archival documents that underpin these findings make it possible to appreciate the valuable diplomatic role that musicians like Pietrobono were already playing during the second half of the fifteenth century.

\section{ABSTRACT}

Praised by poets, scholars, and fellow musicians of his day, the singer, lutenist, and teacher Pietrobono Burzelli (ca. 1417-97) achieved international renown for his skill at improvisational performances on plucked instruments. Until recently, archival documents recorded his presence at many courts on the Italian peninsula and as far away as the Hungarian court. Documents until now unknown to musicologists reveal that Pietrobono also traveled to England. In August 1466 he signed a will and testament in advance of a risky trip "ad partes Anglie" that he was planning to begin the next day.

The testament offers new information about Pietrobono's family, home, and professional relationships. Among the witnesses to this notarial document was his tenorista, Francesco Malacise, as well as important nobles at the Este court, including the master of the stables. Additional archival evidence reveals that Pietrobono and his colleagues had been charged with bringing lavish gifts to King Edward IV on behalf of the Este court and purchasing racehorses for Borso d'Este. The journey to England thus demonstrates the long reach of Pietrobono's reputation and offers an early example of the diplomatic responsibilities with which he would be regularly charged later in life. The testament also provides new and intriguing evidence of music and musicians traveling between Italy and England during the second half of the fifteenth century.

Keywords: Pietrobono Burzelli, Ferrara, diplomacy, Este family, English music, lute playing, Francesco Malacise, horses 


\section{Appendix}

Pietrobono's will and testament. Ferrara, Archivio di Stato, Archivio Notarile Antico di Ferrara, Notaio Mengo dall'Armi, matr. 113, pacco 1, prot. 1465, fol. 33 (12 August 1466); transcribed in Franceschini, Artisti a Ferrara, 1:677-78 (\#1087). Translation by the author.

[1] In Christi nomine. Amen. Divine inspirationis donum est et provide mentis arbitrium ut antequam superveniat mortis hora quilibet sit paratus se et sua bona ordinare. [2] Quapropter excellentissimus hac etate nostra cytharista Petrusbonus filius quondam Baptiste civis Ferrarie de contrata Sancti Gulielmi burgi Ferrarie crastina die discedere habens et profecturus ad partes Anglie, timens casus fortuitos qui in huiusmodi itinere sibi contingere possent ac mortis iudittium, nolens intestatus decedere dispositionem et ordinationem omnium suorum bonorum mobilium et immobilium, iurium et actionum per hoc presens suum ultimum nuncupativum testamentum sine scriptis in hunc modum facere procuravit et fecit.

[3] Primo namque animam suam omnipotenti Deo pie misericorditerque commendavit ut cum contingerit ipsam migrare ex hoc seculo altissimus Redemptor noster dignetur eam in celesti patria commendatam habere ac collocare.

[4] Item reliquit per infrascriptam eius uxorem et heredem exequi et adimpleri quecunque vota que adimpleri debebant per ipsum testatorem expensis dicte hereditatis, videlicet visitationis Annuntiate gloriosissime Virginis de Florentia, Sancti Belini de la Fratta et aliorum locorum que bene nota sunt ipsi eius uxori et cui expressisse clare dixit et de eis notitiam habere.

[5] Suos commissarios et huius testamenti executores elegit et esse voluit dictus testator clarissimum iurisconsultum dominum Augustinum de Bonfrancischis de Arimino civem Ferrarie, Iacobum Laurentium notarium eius testatoris cognatum et me Mengum notarium infrascriptum. Quibus suis comissariis etc.

[6] In omnibus autem suis bonis mobilibus et immobilibus, iuribus et actionibus presentibus et futuris ubicunque consistant et esse reperiantur dictus testator sibi heredem universalem instituit, ellegit et esse voluit honestam dominam Antoniam eius uxorem ipsa servante vitam vidualem castam et honestam. [7] Si vero dicta domina Antonia ad secunda vota transiret vel decederet, altero istorum duorum casuum tunc ipse testator substituit pauperes Christi civitatis Ferrarie suos heredes universales.

[8] Et hoc suum ultimum testamentum et sua ultima voluntas quod et quam valere voluit iure testamenti etc. Cassans, irritans [et anullans] etc.

[9] Lectum et publicatum fuit dictum testamentum per me Mengum de Armis notarium infrascriptum de voluntate et iussu dicti testatoris anno Nativitatis dominici 1466, indictione $14^{\wedge}$, die duodecimo [ fol. $34 r$ ] mensis augusti, in contrata Sancti Gulielmi burgi Ferrarie, in orto casalis et domus residentie dicti testatoris.

[10] Ad cuius testamenti publicationem interfuerunt infrascripti testes vocati et ore proprio testatoris rogati, videlicet: 
Nobilis vir Blasius de Birago de Mediolano aulicus et magister stabuli Illustrissimi domini nostri Ducis filius quondam

Leonellus de Bruno filius quondam Bartolomei de contrata Sancti Nicolai Superioris.

Iacobus Laurentius de Vancis notarius filius Magistri Marci de contrata Bucecanalium.

Hieronymus de Bonfrancischis de Arimino campsor filius quondam domini Ugulini de contrata Sancti Gregorii.

Franciscus filius quondam Blasii de Montepulzano civis Ferrarie de contrata Sancti Salvatoris eius Petriboni testatoris tenorista.

Michael Antonioli de Porto sartor habitator Ferrarie in contrata Sancti Salvatoris.

Jo[hannes] Thomas dictus Turchetus de Regio filius quondam Petri Pauli, habitator in domo dicti testatoris.

Ego Mengus de Armis notarius etc.

[1] In the name of Christ. Amen. It is the gift of divine inspiration and the judgment of a provident mind that before anyone arrives at the hour of death, he shall be ready to set himself and his property in order. [2] Wherefore the most excellent lutenist in our age, Pietrobono, son of the late Battista, citizen of Ferrara, of the contrada of Borgo San Guglielmo in Ferrara, planning to depart on the next day and set out for the region of England, fearing accidental calamities which might befall him in some way on such a journey as well as the judgment of death, wishing not to die intestate, has caused to be made and made a disposition and ordering of all his property, movable and immovable, by means of this his final noncupative testament without writing [i.e., dictated by a testator to a notary] in this manner.

[3] Namely, first he entrusted his soul devoutly and compassionately to the Almighty God so that when it shall happen to pass from this world, our Most High Redeemer may deign to keep and place him in the heavenly realm.

[4] Item, he has bequeathed to be carried out and fulfilled by his wife and heir undermentioned whatever vows ought to have been fulfilled by the said testator at the expense of the said estate, namely, to visit the Annunziata of the most glorious Virgin in Florence, San Bellino in Fratta [Polesine], and other places which are well known to his said wife. He asserted that he expressed this clearly to her and that she is acquainted with these places.

[5] As his trustees and executors of this testament he chose and wished to be the illustrious jurist ser Agostino Bonfranceschi da Rimini, citizen of Ferrara, the notary Jacopo Lorenzo, brother-in-law of this testator, and me, Mengo, notary of the testament below. To his trustees etc.

[6] Moreover, in all of his property, moveable and immovable, rights and actions present and future wherever they may exist and be found to be, the said testator 
appointed, chose, and wished to be his universal heir the honorable lady Antonia, his wife, so long as she shall maintain a chaste and honorable widowed life. [7] If, however, the said lady Antonia were to cross to a second vow [i.e., remarry] or die, of the second of these cases, thereupon this testator substitutes the poveri di Cristo of the city of Ferrara as his universal heirs.

[8] And this is his last testament and his last will, both of which he wishes to prevail by law of the testament, etc. Quashing, invalidating, [and annulling,] etc. ${ }^{84}$

[9] The said testament was read and made public by me, Mengo dall'Armi, notary of the underwritten, according to the wish and command of the said testator in the year of the Nativity of the Lord 1466, 14th Indiction, on the 12th day [ fol. 34r] of the month of August, in the contrada of Borgo San Guglielmo in Ferrara, in the garden of the casale and home of the resident, the said testator.

[10] At the disclosure of which testament the undersigned witnesses were present, having been summoned and asked for by the testator's mouth, namely:

The nobleman Biagio Birago da Milano, courtier and master of the stable of our Most Illustrious Lord Duke, son of the late

Leonello Bruno, son of the late Bartolomeo, of the contrada of San Nicolò Superiore.

Jacopo Lorenzo Vanci, notary, son of Messer Marco of the contrada of Boccacanale.

Girolamo Bonfranceschi da Rimini, banker, son of the late Lord Ugolino of the contrada of San Gregorio.

Francesco, son of the late Biagio of Montepulciano, citizen of Ferrara, of the contrada of San Salvatore, tenorista of the testifying Pietrobono.

Michele Antonioli of Porto, tailor, resident of Ferrara in the contrada of San Salvatore.

Giovanni Tommaso called Turchetto of Reggio, son of the late Pierpaolo, resident in the home of the said testator.

I, Mengo dell'Armi, notary, etc.

84 This formulaic language, found in most medieval testaments, indicates that this document supplants any existing or future testament. The notary has abbreviated this text here. 